\title{
Design and development of solar desalination plant
}

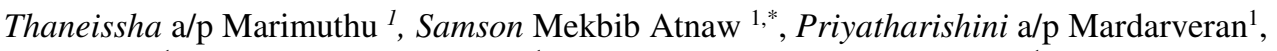 \\ Sim Shu Yi ${ }^{1}$, Mazlin Azura binti Usop ${ }^{1}$, Muhammad Khairi bin Md Gapar ${ }^{1}$, Siti Aishah \\ Binti Rusdan ${ }^{1}$, Roshahliza Binti M Ramli ${ }^{1}$ and Shaharin A. Sulaiman ${ }^{2}$ \\ ${ }^{1}$ Faculty of Engineering Technology, University Malaysia Pahang, 26300, Gambang, Pahang, \\ Malaysia \\ ${ }^{2}$ Department of Mechanical Engineering, Universiti Teknologi PETRONAS, 31750, Tronoh, Perak, \\ Malaysia
}

\begin{abstract}
Direct sunlight has been utilized long back for desalination of water. The desalination process takes place in solar still. Solar still is a device that converts saline water to potable water. This process requires seawater and sunlight which are widely available on Earth. However, the current solar desalination generation capacity is generally low and has high installation cost. Hence, there is a need for the enhancement of the productivity which can be achieved through few modifications. This paper explores the challenges and opportunities of solar water desalination worldwide. It presents a comprehensive review of solar desalination technologies that have been developed in recent years which covers the economic and environmental aspects.
\end{abstract}

\section{Background of solar desalination}

Water and energy are two inseparable and vital commodities for human, plant and animal sustainability on earth. With total global water reserves of about 1.4 billion $\mathrm{km}^{3}$, around $97.5 \%$ of it is in the oceans and the remaining $2.5 \%$ is fresh water present in the atmosphere, ice mountains, freshwater lakes and groundwater as shown in Figure 1 [1].

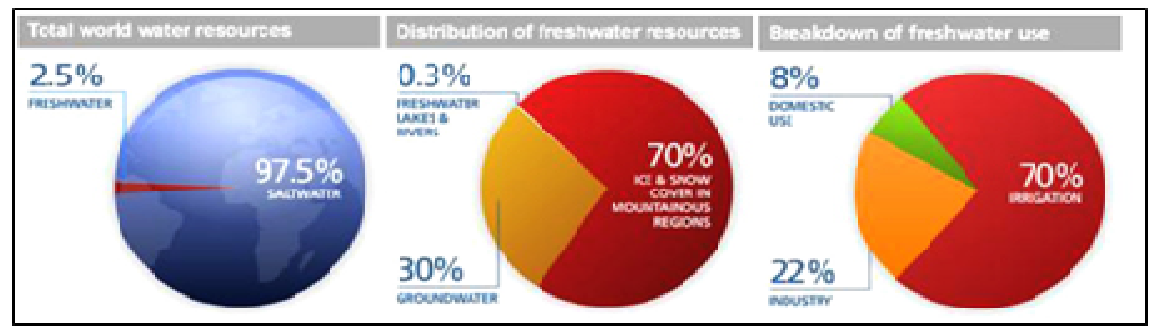

Fig 1. Distribution of world water resources

*Corresponding author: mekbibsams@ump.edu.my 
Since those days, humans survive with water from rivers, lakes, and recently aquifers where ground water can be extracted as potable water which is less than $1 \%$ of total amount of the water on Earth.

\section{Classifications of solar desalination}

Figure 2 shows the classification of solar still.

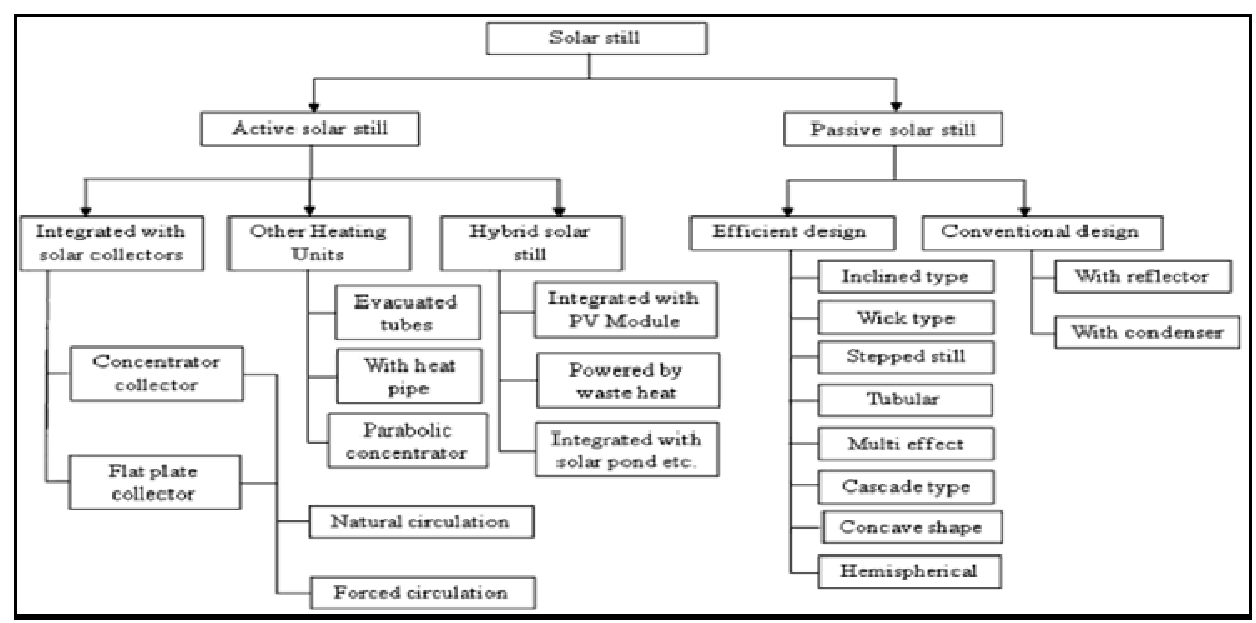

Fig 2. Classifications of solar still [2]

\subsection{Passive solar still}

Passive solar stills will be very simple in construction and operation. Passive solar stills only utilize available solar energy to remove the impurity in contaminated water, thus it is safe, clean, eco-friendly, and energy saving.

\subsubsection{Basin type solar still}

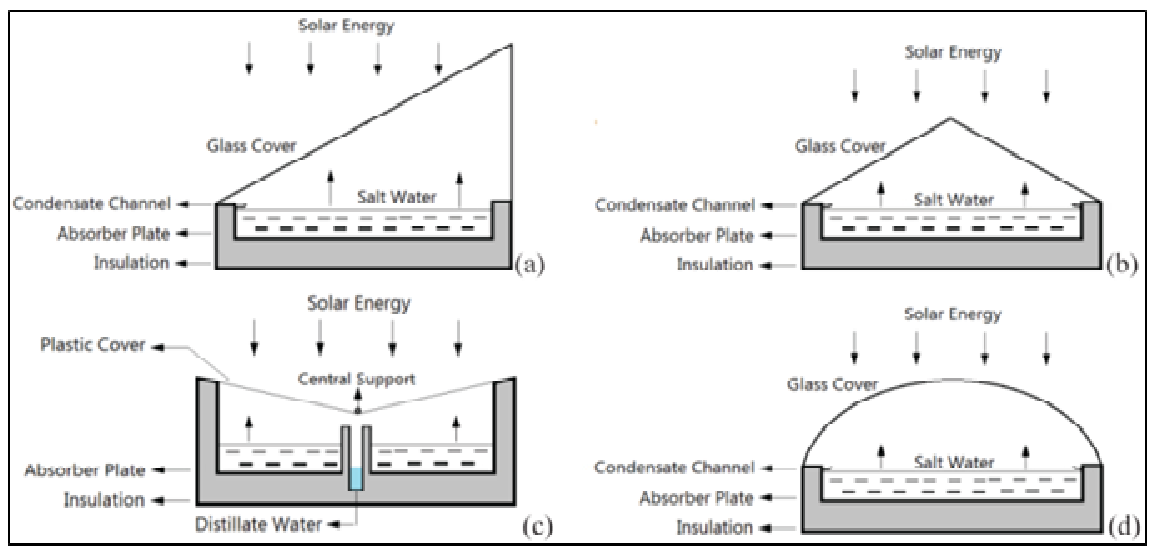

Fig 3. (a) single-slope basin still, (b) double-slope basin still, (c) V-type solar still, (d) Hemispherical type solar still [3] 
As shown in Figure 3, basin type solar stills have been modified into several types according to their cover designs such as single slope, double slope, V-type and hemispherical. This basin type solar still is the most widely used nowadays due to its simplicity and low cost. Zaki et al. acclaims that the average distillate production rate of a standard single-basin still is between $2 \mathrm{~L} / \mathrm{m}^{2}$ depending on the insulation quality [4]. However, the productivity varies according to the design. The concept of this process is very simple where the still traps solar energy within the enclosure. This heats up the water causing evaporation and condensation on the inner face of the sloping transparent cover. This distilled water is generally potable because all the salts, inorganic and organic components and microbes are left behind in the bath. However, few modifications have been done in order to increase the productivity of basin type by integrating with solar panel or heater which refers as active solar still. After few improvements have been made, today's state-of-the-art single-effect solar stills have an efficiency of about 30-40\% [5].

\subsubsection{Weir type cascade solar still}

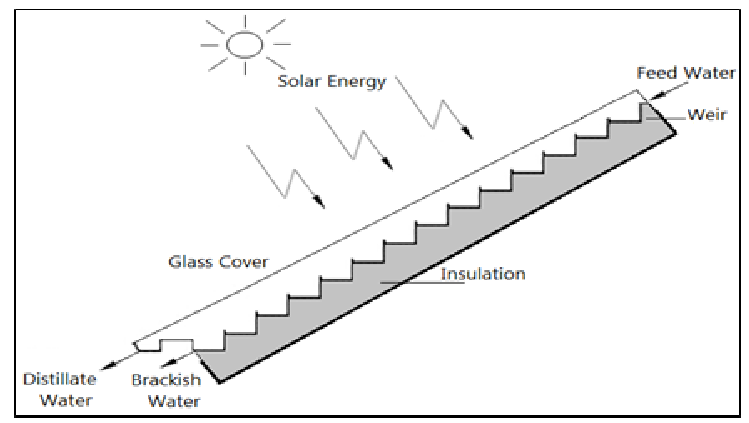

Fig 4. Weir type cascade solar still [6]

Figure 4 shows the weir type cascade solar still. The advantages of weir-type cascade solar stills is it do not suffer from dry spot or channelization problems since the brine is forced to flow each step one by one without leaving any dry surface on the absorber plate which increases the efficiency. Further study have been done to these weir-type cascade stills by including wick on each cascaded steps and phase change material beneath the absorber surface to store energy when it is abundant and give it back to the salt water when it is needed during cloudy days [7]. Table 1 shows the productivity of the weir-type still that is approximately $20 \%$ higher than conventional basin-type solar still. Besides, the average productivity of the still is approximately $5.5 \mathrm{~L} / \mathrm{m}^{2}$ in a day.

Table 1. Distillate productivity from the conventional basin and weir-type stills, September 2006 [8]

\begin{tabular}{|c|c|c|}
\hline \multirow{2}{*}{ Day } & \multicolumn{2}{|c|}{ Distillate productivity (1/m3/day) } \\
\cline { 2 - 3 } & $\begin{array}{c}\text { Conventional basin- } \\
\text { type still }\end{array}$ & $\begin{array}{c}\text { Weir-type still } \\
\text { (single-pane) }\end{array}$ \\
\hline 8 September & 4.6 & 5.5 \\
\hline 9 September & 5.1 & 6.3 \\
\hline 10 September & 4.3 & 5.2 \\
\hline 11 September & 4.8 & 5.6 \\
\hline 12 September & 4.9 & 5.8 \\
\hline 13 September & 4.2 & 5.0 \\
\hline 14 September & 3.4 & 4.1 \\
\hline
\end{tabular}




\subsection{Active solar still}

Active solar still is a still integrated with a solar panel or concentrator. Active solar stills receive additional thermal energy from an outer source to the water in the basin which improves the rate of evaporation.

\subsubsection{Parabolic trough solar collector}

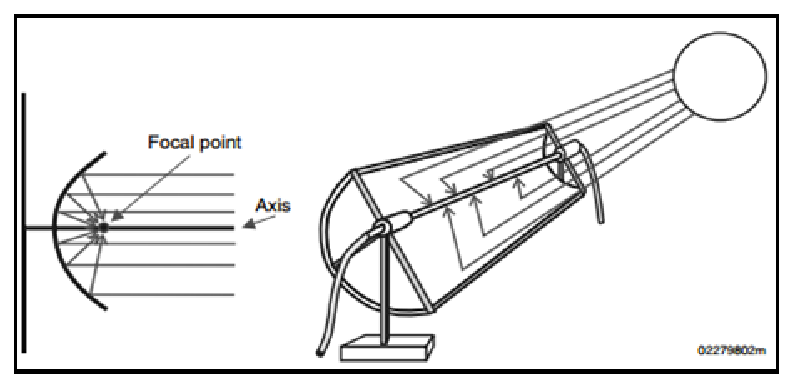

Fig 5. Parabolic trough solar collector on the right side and the concentrated focal point on the left side [9]

The parabola is an intriguing geometric shape with important practical uses including concentrating sunlight as shown in Figure 5. The curve of a parabola is set as such that light travelling parallel to the axis of a parabolic mirror will reflect to a single focal point from any place along the curve. Since the sun is far away, all light coming directly from it is essentially parallel, so if the parabola is facing the sun, the sunlight is concentrated at the focal point. A parabolic trough extends the parabolic shape to three dimensions along a single direction, creating a focal line along which the absorber tube is run [9]. Some design goals of a parabolic trough solar collector achieve high performance, reliability and durability. The drawback of this solar still is the cost is high and often used for large scale purpose. Improvements have been suggested in reflective and absorbent coatings which will incrementally improve economics, but still the cost is high.

\subsubsection{Point-focus parabolic solar still}

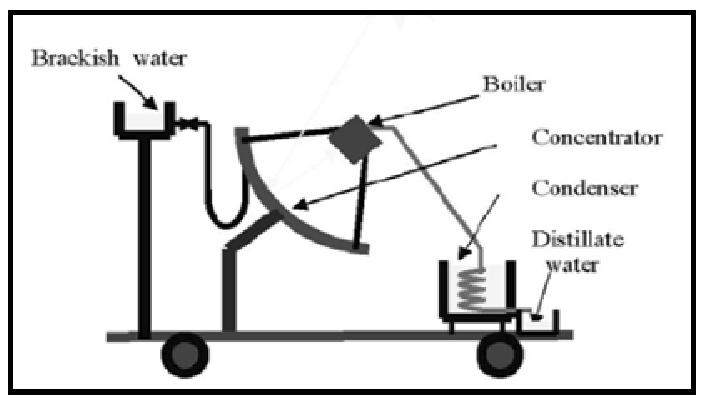

Fig 6. Point-focus parabolic solar still [10]

The point-focus parabolic solar still (PPSS) is the active solar still type as shown in Figure 6. This system consists of a parabolic dish concentrator, a single or two axis sun tracker based on programmable logic controllers (PLCs) and condenser. The concentrating solar energy on the focal line of a parabolic trough has line that usually a pipe that contains a thermal fluid which heats it up to high temperature [11]. Then, to improve the efficiency, 
heat exchanger can be added where the fluid is pumped to a heat exchanger which heats water. It eventually vaporizes and immediately condensed which is later withdrawn as desalinated water. The productivity of such units is high. Improvements have been made through high temperature and low heat loss area of the still basin or the absorber which is located on the focal point of parabolic concentrator greatly increases the efficiency of the still [12]. Despite this still's outstanding performance, it has many drawbacks; including the high cost of building and maintaining it, the need for strong direct sunlight, and its fragile nature. The total yield produced for this PPSS is 6.112 L per day for PPSS [11].

\section{Summary table}

Table 2 shows the comparison of productivity for different types of solar stills.

Table 2. Comparison of productivity for solar stills

\begin{tabular}{|c|c|c|c|}
\hline Type of Solar Still & $\begin{array}{c}\text { Methodology/ Modifications/ } \\
\text { Analysis }\end{array}$ & $\begin{array}{l}\text { Capacity } \\
\text { (L/m2/day) }\end{array}$ & References \\
\hline Basin Type Solar Stil & $\begin{array}{l}\text { Simple basin that need for regular } \\
\text { flushing of accumulated salts }\end{array}$ & 2.00 & $\begin{array}{l}\text { Zaki et al.,1993 } \\
\text { [4] }\end{array}$ \\
\hline Wick Still & $\begin{array}{l}\text { Effect of corrugated work by wick } \\
\text { surface on the performance of the still }\end{array}$ & 4.20 & $\begin{array}{c}\text { Kassem,2016 } \\
{[13]}\end{array}$ \\
\hline $\begin{array}{l}\text { Weir type cascade } \\
\text { solar still }\end{array}$ & $\begin{array}{l}\text { Absorber plate, condensing cover, } \\
\text { and insulation }\end{array}$ & 3.85 & $\begin{array}{l}\text { Sadineni et al., } \\
\quad 2006[8]\end{array}$ \\
\hline Spherical Solar Still & $\begin{array}{c}\text { Circular absorber basin coated with } \\
\text { black paint }\end{array}$ & 2.30 & $\begin{array}{l}\text { Arunkumar et } \\
\text { al., } 2012[14]\end{array}$ \\
\hline $\begin{array}{l}\text { Double basin still } \\
\text { coupled to a collector }\end{array}$ & $\begin{array}{l}\text { Double basin solar still integrated } \\
\text { with flat plate solar collector }\end{array}$ & 5.18 & Tiris, 1998 [15] \\
\hline $\begin{array}{l}\text { Point-focus parabolic } \\
\text { solar still }\end{array}$ & $\begin{array}{c}\text { Concentrator (mirror + parabolic dish) } \\
\text { and heat exchanger }\end{array}$ & 3.56 & $\begin{array}{l}\text { Arunkumar et } \\
\text { al., } 2012[14]\end{array}$ \\
\hline
\end{tabular}

\section{Conclusions}

To sum up, water is essential to all living things in Earth as a nutritional requirement, agriculture and industrial processes. Since sunlight and seawater can be obtained abundantly and it is free, there would not be many challenges to get the resources for solar desalination system [16]. In order to come up with an effective solar desalination plant, the evaluation of the effects of environmental and operational parameters should be considered [17]. Therefore, there is a need for on-going research and demonstration projects to gain experience, knowledge and trust in new environmentally friendly technologies as well as a state incentives through the introduction of new polices and financial support.

\section{References}

1. T.A Mateo, Solar powered desalination system, 1 - 78 (2011)

2. H. Manchanda and Kumar, Renew. Energ. (2015)

3. T. AnfasMukram, P.U. Suneesh., Int. J. Innov. Res. Sci. Eng. Technol. 2(7) (2013)

4. G. Zaki, A. Radhwan and A. Balbeid, Sol. Energy. 51. 277-288. (1993) 
5. G. Mink, M. Aboabbous and E. Karmazsin, Sol Energy 62. 309-317 (1998)

6. V. Sivakumar and E.G. Sundaram, Sust. Energ. Rev. 28. 246-64 (2013)

7. H.A Zoori, F.F Tabrizi, F. Sarhaddi and F. Heshmatnezhad, Desalination 325. 113-21 (2013)

8. S.B. Sadineni, R. Hurt, C.K. Halford and R.F. Boehm, J. Energy. 33. 71-80 (2008)

9. Federal Technology Alert. Parabolic-Trough Solar Water Heating. U.S. Department of Energy (DOE) (2000)

10. B. Chaouchi, A. Zrelli and S. Gabsi, Desalination 217. (2007)

11. S. Gorjian, B. Ghobadian, T.H. Teymour and B. Ahmad, Desalination. 352. 1-17(2014)

12. H.M. Qiblawey and F. Banat F, Desalination 220. 633-644 (2008)

13. T.K. Kassem, Int. J. Eng. Technol. Sci. 3 (2016)

14. T.Arunkumar, K. Vinothkumar, A. Ahsan, R. Jayaprakash and S. Kumar, Renew. Energ. (2012)

15. C. Tiris, M.Tiris, Y.Erdalli and M. Sohmen, Energ. Convers. Manage. 8, 853-856 (1998)

16. R. Zailan, A. Razak and M. Firdaus, Int. J. Eng. Technol. Sci. 3 (2015)

17. MNI Siddique and AW Zularisam, Int. J. Chem. Environ. Biol. Sci. (2014) 